\title{
Development of Dutatani Website Using Rapid Application Development
}

\author{
Rosa Delima ${ }^{1}$, Halim Budi Santosa ${ }^{2}$, Joko Purwadi ${ }^{3}$
}

\begin{abstract}
Rapid Application Development (RAD) is a methodology used to develop software. This method is able to reduce time to develop software. This becomes consideration in order to choose the Rapid Application Development as a methodology to develop Dutatani Website. Dutatani is a portal and a part of Integrated Agriculture Information System (IAIS). IAIS is an agriculture information system that has some subsystems that are connected and linked to each other. It also has an integrated database. In particular, Dutatani is able to manage user, manage content, and manage link in the IAIS. This website will be a link to other applications in the IAIS. This article especially discusses the development of the Dutatani Website using Rapid Application Development that is implemented by combining iterative development and system prototyping. There are some phases in the development using the RAD: planning, analysis, main design specific design, implementation and testing, and integrating prototype. This system was developed by a team which consists five members. The implementation of this prototyping technique was done by dividing five people into two groups in which each group had different responsibilities to different module/functions. This website had been developed within 150 days. Thus, in implementing the RAD, it is important for the team leader to monitor continuously. Monitoring is a useful technique to ensure the productivity and performance of each members in order to gain optimal development process.
\end{abstract}

Keywords-Dutatani Website, RAD Method, Iterative Development, System Prototyping.

\section{Pendahuluan}

A web portal/website is an application that applies web technology. Applications developed through this technology will be accessible through an internet network. This network has a wide range so that the applications developed through this technology will be more easily accessed by users.

A website provides various information needed for its users. Website Dutatani is a special application developed as the main website for Integrated Agricultural Information System (IAIS). It is a system developed for data processing, information, and knowledge in agriculture. This system has several subsystems that are planned to be interconnected with an integrated database. The Dutatani website developed will be the main page managing user management, content management, and loading website links to connect with other application websites on the IAIS.

1, 2, 3 Lecturer, Faculty of Information Technology Duta Wacana Christian University, Jl. Dr. Wahidin Sudirohusodo No. 5-25 Yogyakarta 55224 (tlp: 0274-563929; fax: 0274-513235; e-mail: rosadelima@staff.ukdw.ac.id, jokop@staff.ukdw.ac.id)
In its development process, the Dutatani website uses Rapid Application Development (RAD) method. It is one of the software development models that has advantages in terms of fast application development while maintaining product quality. This factor is the basis for the selection of the system development method on the Dutatani website.

\section{LITERATURE REVIEW}

This section discusses the concepts and techniques in the RAD and the agricultural websites that have ever been developed

\section{A. Rapid Application Development (RAD)}

RAD is a set of methods developed to overcome the weaknesses of traditional system development methods, such as waterfall models and their variants [1]. It is a method used in rapid application development cycles and also provides good software quality compared to traditional software engineering approaches. Through a rapid application development process, organizations can reduce software development and maintenance costs [2]. It was first introduced by James Martin in the 90s. James Martin believed that the RAD model is a more flexible and adaptive application development model for changing user needs and ensures fast developed system quality at minimal cost [3]. In its application, it emphasizes the short planning process by focusing on software development process consisting of development, testing and feedback [4].

Although the RAD method is believed to be capable of supporting rapid software development processes, but in its application, this method has risks that can arise, namely reduced system level scalability, reduced power efficiency and time in the process of system development, and the short time of system development will have an impact on Software quality [3]. Therefore, in its application, the RAD method should be supported by a team of developers who are experts in software engineering resulting in high cost of development and hardware specifications required. It is strongly recommended to carry out a combination of RAD method implementation with other system development methods accompanied by good support and project management tools [3]. The project manager has responsibility in performing documentation, analyzing each system component, and giving priority to important components of the system. Managers are also responsible for controlling the communication process between team members and stakeholders involved in the system development process [2].

The RAD model has four main stages, namely Requirement Planning, User Design, Construction, and Implementation [3]. In implementation, there are three ways of implementation, 
namely iterative development, system prototyping, and throwaway prototyping [1]. Through iterative development or iterative development, the whole project is broken down into several series/versions that will be sequentially developed. The most important thing in this approach is to develop the first version of the system. This version is developed quickly by applying the mini waterfall method. Once implemented, users can provide feedback for system development on the next version [1]. In this technique, it is required a good understanding of the scope of the project, so that the development team can build systems with comprehensive functional capabilities in just a short time, for example 60 to 90 days [5]. The stages in the iterative development are shown in Fig. 1.

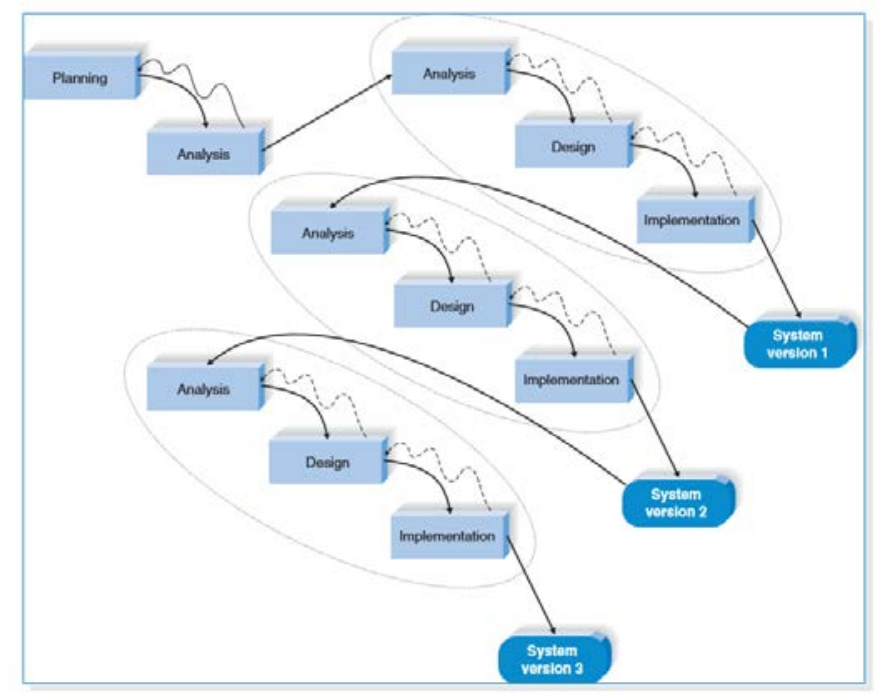

Fig. 1 Stages of the RAD model using iterative development [1].

In the prototyping system development techniques, it is performed the phase of analysis, design, and implementation in order for the system to be able to be developed quickly. The system that is the first version contains only the minimal features needed. Furthermore, the system will be introduced to users. All comments and feedback from users will be analyzed by the developers and used as a basis for performing analysis, design, and re-implementation for the next system prototype. This cycle will continue until the developers, users, and fund provider teams agree that the system has covered all the needs and functionality required by the organization [1]. The stages in the development of the prototyping system are shown in Fig. 2.

While in throwaway prototyping techniques, the initial application development process is the same as the prototyping technique, but after the initial prototype is developed, it is more likely to explore alternative design possibilities than develop a new system prototype for further application development. Systems developed using this technique may require several prototype designs during the analysis and design phase. Each prototype is used to minimize system-related risks by making confirmation of important issues already understood before the final product is developed. Once approval is obtained, a system redesign will be followed by the development of the final product. Meanwhile the design of the prototype of the previous system will be discarded or not used anymore. This is the difference between throwaway prototyping and system prototyping [1]. The stages in the throwaway prototyping technique are shown in Fig. 3.

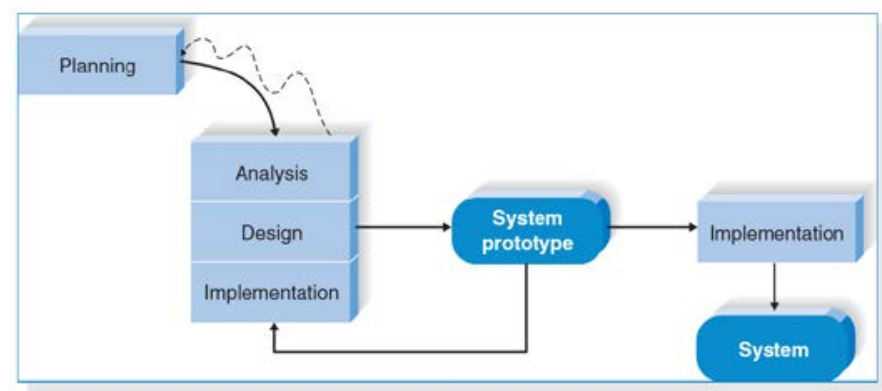

Fig. 2 Stages of the RAD model using system prototyping [1]

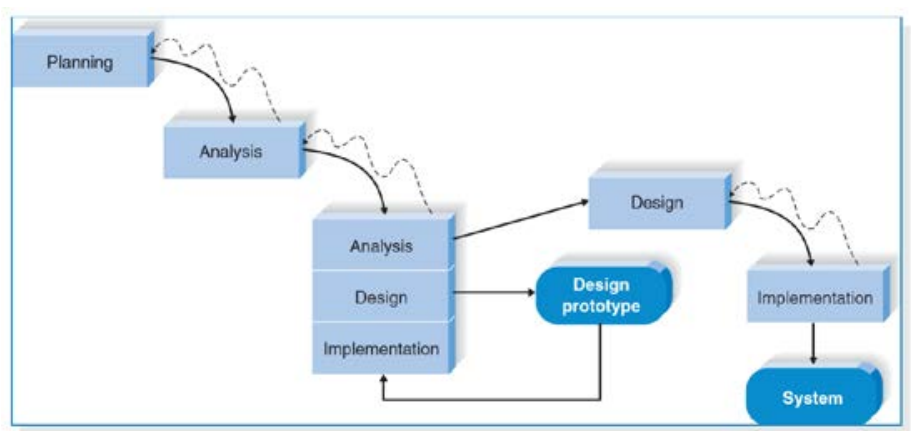

Fig. 3 Stages in the RAD model using throwaway prototyping [1]

\section{B. Agriculture Websites}

Agricultural websites have been developed in several countries, including Indonesia. Agricultural Information System using web technology is often referred to as eAgriculture. There are several understandings of the definitions of e-agriculture, such as e-agriculture is understood as 1) information related to agriculture; 2) technology or tools for information and communication; 3) various types of agricultural information; 4) all stakeholders who will benefit from agriculture; and 5) the perceived benefits of agriculture from the application of ICT applications [6]. In practice, eAgriculture can be geographic information systems, remote sensing, and various wireless devices [7]. Several eagriculture applications have been developed, including eChoupal (India), Agricultural Market Information System (Bangladesh), and Infotrade (Uganda) [8].

E-Choupal is one of the marketplaces appointed by the government of India as the official place to trade and sell agricultural products. The E-Choupal provides access to the agricultural trade market. In addition, it also includes an analysis of product value changes available in India. Fig. 4 and Fig. 5 show the supply chain analysis of the application and the relationship between farmers and stakeholders facilitated by the application [9].

In Fig. 4, it appears that the supply chain from e-Choupal starts from the pricing process, warehouse system, inspection, payment, up to the intermediary system. Meanwhile, Fig. 5 illustrates the relationship of farmers with retail traders. Farmers can have access to ritail merchants in providing 
fertilizers, seeds, pesticides, and other chemicals. In addition, Fig. 5 also illustrates that farmers have access to government, traders, and financial aid [9].

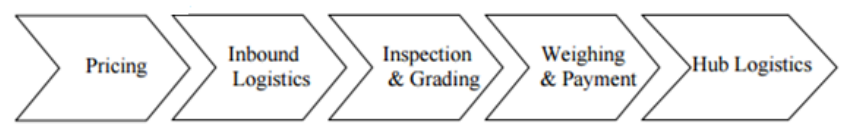

Fig. 4 Supply chain analysis in e-Choupal [9].

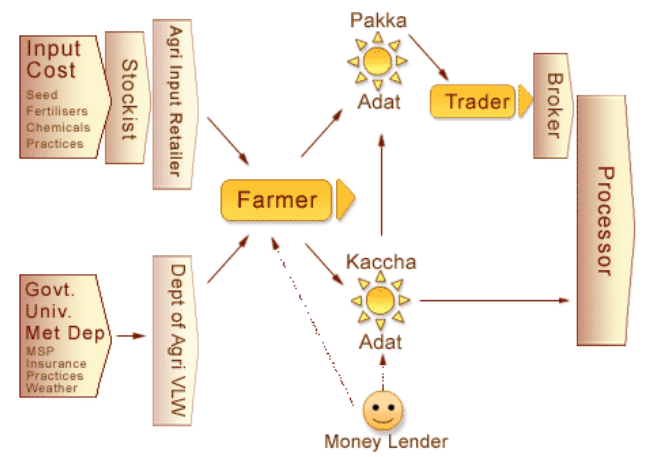

Fig. 5 The relationship between farmers and stakeholders in e-Choupal [10].

In Bangladesh, it is developed an agricultural website called Agricultural Market Information System (AMIS). AMIS was established at the request of the G20 Agriculture Minister in 2011. AMIS is a trade standard of several relevant agencies to improve food market transparency and encourage coordination of policy actions in response to market uncertainty. It focuses on four very important crops in international food markets, namely wheat, corn, rice, and soybeans [11].

The AMIS as an information system has several functions, namely: (1) providing the latest information about supply, demand, and stock of agricultural products; (2) producing monthly reports of the global market situation and its development; (3) providing information on emerging issues affecting the international market; (4) strengthening of three systems in participating countries in the AMIS and promoting the use of methods for data collection and forecasting; and (5) informing the development of the food market and identifying critical conditions about the current policy. Fig. 6 is an AMIS interface image [11].

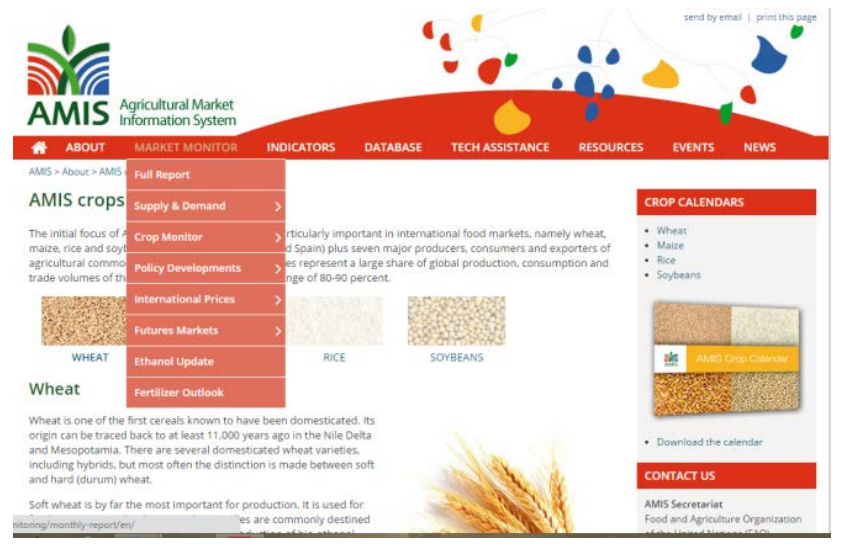

Fig. 6 AMIS interface [11].
AGMIS is a supporting application of Infotrade that serves to provide detailed information on commodity prices based on region and market type. Meanwhile, LaMIS is an online application built for partner organizations in order to access market information owned by the system. Unlike the previous two applications, FARMIS emphasizes more on the process of collecting data on agricultural activities conducted by farmers. The system is equipped with the ability to produce information that farmers need to improve agricultural productivity, for example information on how to calculate the required seed quantity or cost information required for agricultural production. Fig. 7 is an interface image of the Infotrade app [12].

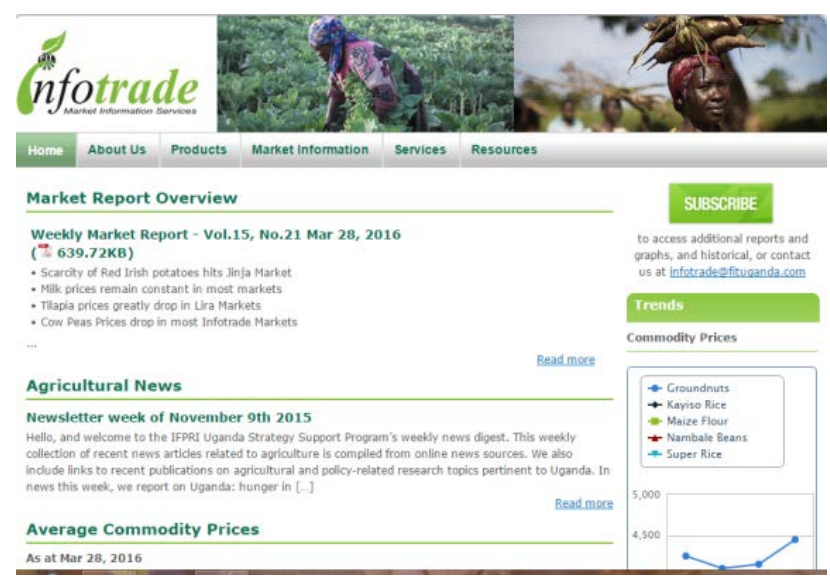

Fig. 7 Infotrade interface application [12].

Indonesia also has several agricultural websites. Based on the results of research that has been done, it is known that most agricultural web pages in Indonesian language have a function as a means of publishing articles/journals, public services, and the sale of agricultural products [13]. Only a small portion of the agricultural web page is used as an information medium, a source of knowledge of cultivation techniques, and a source of agricultural databases. Meanwhile, the ownership status of web pages in Indonesia is still dominated by governments, individuals, and companies. There are still very few agricultural websites belonging to colleges and non-governmental organizations. Therefore, universities or educational institutions have an enormous opportunity to participate actively in disseminating data, information, and knowledge in agriculture [13]

\section{METHODOLOGY}

This research applies the RAD software development model. The application of the RAD model combines iterative development and prototyping techniques. The system is divided into two main parts with four development team members. The process of website development is done through several stages, namely: planning, analysis, main design, specific design, manufacture and test system, and end with system integration process from two development team. The website development stages of the Dutatani are shown in Fig. 8. 


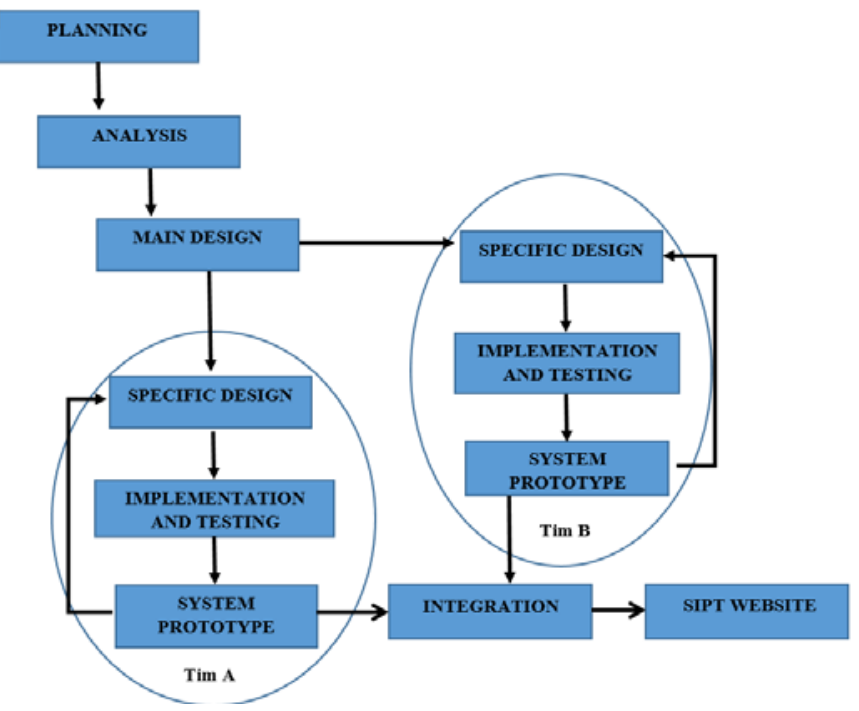

Fig. 8 Stages of the application of the RAD method in website development.

From Fig. 8, it can be seen that generally the process is divided into two stages, namely the iterative development stage of the planning, analysis, and main design. After that the application development process is continued by way of prototyping system. System prototyping consists of specific design activities, the implementation or manufacture of systems along with the testing process, and prototype system as a result of the system-making process. Furthermore, the products of both teams were integrated until the resulting product is Dutatani website. Iterative development is done by two development teams, each of which has the responsibility of building features from different Dutatani websites.

\section{A. Planning}

Planning is an early stage in the system development process. This stage consists of planning time and resources needed for system development. For time planning, it was determined that the system development process would take place in two stages. The first phase focused on the development of the Dutatani website. The maximum time of the application work had been planned for 8 months starting from May 2016 until December 2016. The second phase focused on the addition of service-based system capabilities on the Dutatani website. For the second phase, the development of the website was also planned to last for 8 months, starting April 2017 until November 2017. This article only discusses the development of the website in the first stage. The two stages are planned to involve a five-member development team.

From the results of the study, it is known that the system development time had run for 150 days or 30 weeks, with the number of development teams as many as five people. This means that the system development process could be completed faster than the planning process. Meanwhile, the software used for system development was the programming language PHP and MySQL as the database and Framework Code Igniter.

\section{B. Analysis}

Dutatani website is the main website page that will lead the system users to be able to access data and information available on the IAIS. Based on these functions, in the analysis phase, user-related research of the system and feature analysis will be provided by the system.

An analysis of users and features on the website was done through literature studies related to the application of agricultural information systems in some countries [8], [13]. Based on the literature study, it is known that there are four main stakeholders in an agricultural information system, ie farmers, academics, government, and businesspeople [14]. For the features contained on the website, determined three main features, namely user management, content management, and link management on the system.

User management features were determined based on the function of the website that became the main page to access applications incorporated in the IAIS. This feature is the most feature in an information system. The second feature is content management. The development of this feature is based on information and communication needs for the users of the system. Through this feature users can share information and simultaneously communicate online with other users related to agricultural topics. The existence of this feature is expected to complement the conventional communication process that has been done by farmers in Indonesia [15]

\section{Main Design}

System design is divided into two stages, namely the design of the main system and system design specifically. The design of the main system includes design use case diagram, database design, and design of menu layout and information on the website.

Use Case diagram the for Dutatani websites involved six users of portal or website administrators, farmers, representatives of farmer groups, academics, government representatives, and businesspeople. The use case diagram of the Dutatani website is shown in Fig. 9. There are nine main functions of the system:

1) User Management: The portal administrator can add users from all existing user categories. The portal administrator also has the authority to remove/deactivate and modify user data that has been entered into the system database.

2) User Category Management: There are several categories of existing users, ie farmers, academics, government representatives, and businesspeople. Portal administrators can add user categories when there are future developments.

3) Internal Organization Management Unit: The portal administrator can add, change, and delete internal organizational units.

4) News Management: The portal administrator can add and delete news.

5) Content Management and Content Topics: The portal administrator can view and change the content contained within the agricultural portal. 
6) Agricultural Topic Information: Users can view information on agricultural topics inside agricultural portals.

7) User information and Activities: each category of users can view the user's personal information.

8) Website Access Information: The portal administrator can view the website access list.

9) User Registration: Administrators can register users to $\log$ into the agricultural portal system. Unregistered users can also enroll themselves in the agricultural portal system.

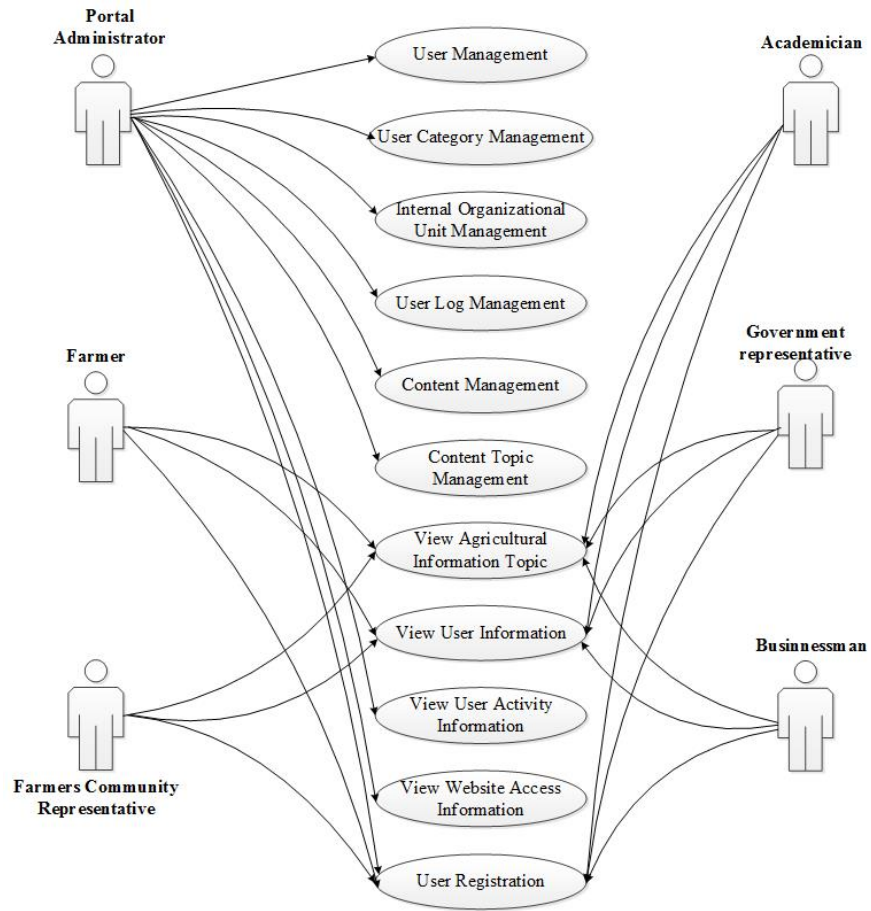

Fig. 9 Use of case diagram of Dutatani website.

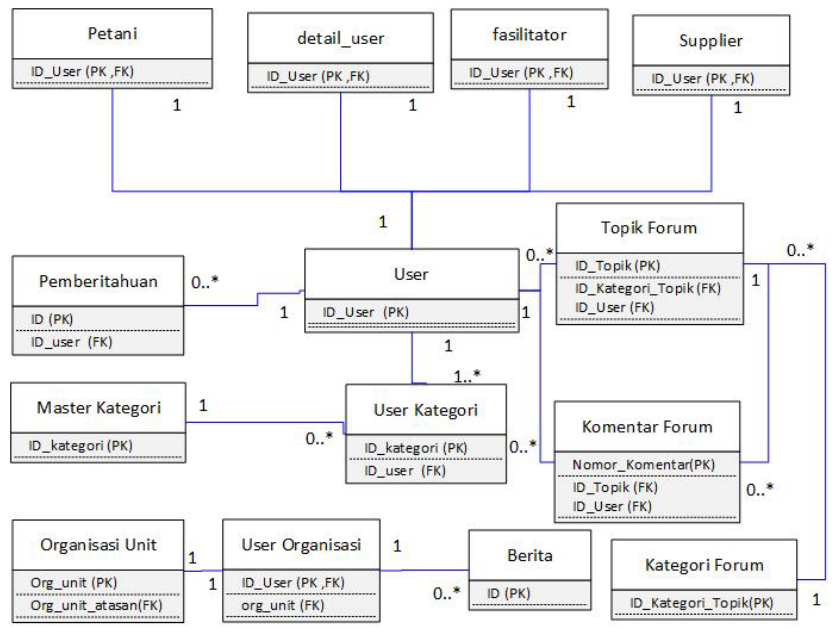

Fig. 10 Class diagram of Dutatani website.

The next major design is the system database design. The Dutatani website has 15 data entities that include data about users, data about the forum, and data about website content. Descriptions of all Dutatani website entities are presented in
Table I, while the class diagram for the system is shown in Fig. 10.

The last major design includes the design of the menu layout and information on the website. For the menu layout, it is agreed that all options menu will be arranged hierarchically on the left side of the web page. While the basic color of the web agreed is green with black, red, blue, and white support.

TABLE I

ENTITY DESCRIPTION ON DUTATANI WEBSITE

\begin{tabular}{|c|c|c|}
\hline Entity Data & Description & Logical Component \\
\hline User & Store master user data & Master_user \\
\hline Detail User & $\begin{array}{l}\text { Store master data of } \\
\text { detailed user }\end{array}$ & Master_detail_user \\
\hline User Kategory & $\begin{array}{l}\text { Store category data per } \\
\text { user }\end{array}$ & Master_user_kat \\
\hline Log user & $\begin{array}{l}\text { Store all users' activities } \\
\text { user }\end{array}$ & Log_user_trans \\
\hline Master_aktivitas & $\begin{array}{l}\text { Store master data of } \\
\text { activities }\end{array}$ & Master_aktivitas \\
\hline User Organisasi & $\begin{array}{l}\text { Store employee data for } \\
\text { the sections that are in } \\
\text { the study group of } \\
\text { agricultural information } \\
\text { systems }\end{array}$ & Master_user_org \\
\hline Organisasi unit & $\begin{array}{l}\text { Store master data of } \\
\text { organizational units in } \\
\text { study groups }\end{array}$ & Master_org_unit \\
\hline Petani & $\begin{array}{l}\text { Store master data of } \\
\text { farmers }\end{array}$ & Master_petani \\
\hline Supplier & Store the master supplier & Master_supplier \\
\hline Fasilitator & $\begin{array}{l}\text { Store master data of } \\
\text { facilitators }\end{array}$ & Master_fasilitator \\
\hline Topik forum & Store forum topics & Trans_topik_diskusi \\
\hline Kategori topik & Store topic categories & $\begin{array}{l}\text { Master_kategori_topi } \\
\mathrm{k}\end{array}$ \\
\hline Komentar Forum & Store forum comments & $\begin{array}{l}\text { Trans_komentar_dis } \\
\text { kusi }\end{array}$ \\
\hline About Us & Store about us content & about \\
\hline Berita & Store news & $\begin{array}{l}\text { Master_berita_infor } \\
\text { masi }\end{array}$ \\
\hline Pemberitahuan & Store user notification & pemberitahuan \\
\hline
\end{tabular}

\section{Specific Design}

Specific design is a Dutatani website application design tailored to the work agreed on two development teams. The first website developer team (Team A) is responsible for user management and news management features. While the second development team (Team B) is responsible for developing the features of discussion forums, information management, and web pages. The system-specific design includes activity diagrams and input designs. Overall, the system has 13 activities, namely user registration, user login, user activation, disable user, change port admin, remove admin portal, add work unit, change work unit, delete work unit, add discussion, add news, add criticism suggestion, and remove suggestion criticism. One of the activity diagrams is shown in Fig. 11. This figure displays an activity diagram for user registration. The initial process of registration is done by entering the user category, as shown in Fig. 12. Furthermore, 
the user is requested to enter account information including Personal Identification Number (PIN), username, and password, as shown in Fig. 13. After the data validation process on the account, then the user is requested to enter the personal data information, as shown in Fig. 14. The system will perform validation related attributes that should not be null. If the input data has been successfully validated, the user is actively registered on the system and the link will go directly to the user page.

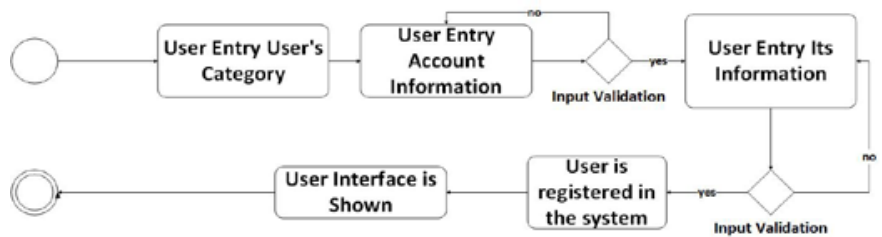

Fig. 11 Diagram of user registration.

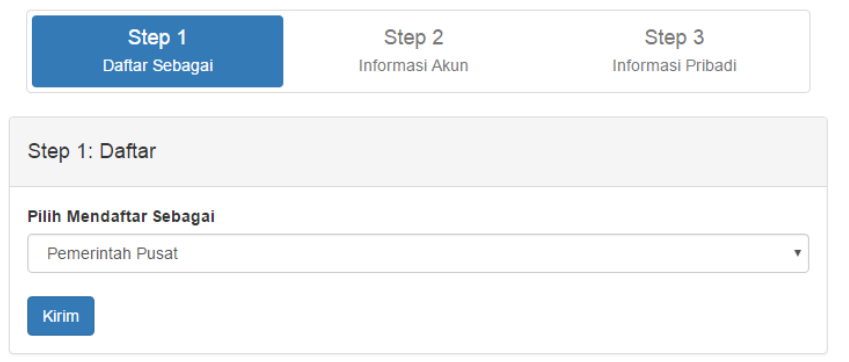

Fig. 12 Stage 1 of user registration.

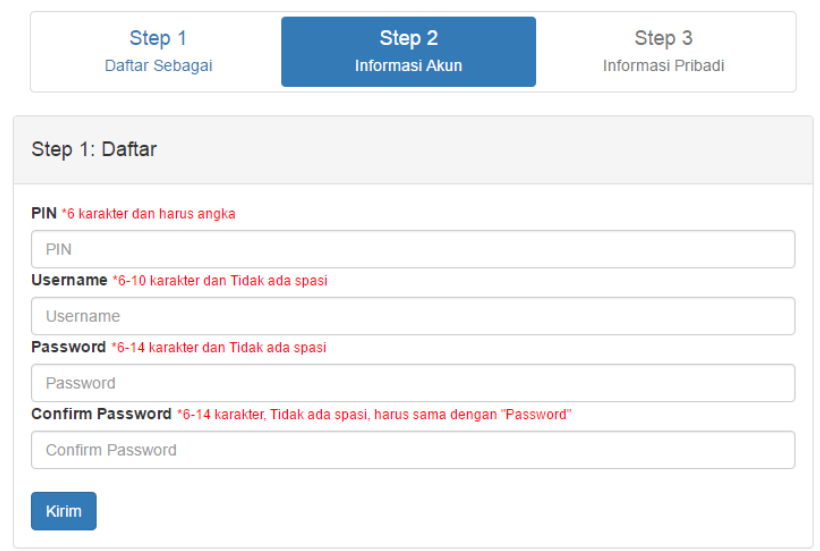

Fig. 13 Stage 2 of user registration.

\section{IMPLEMENTATION AND ANALYSIS}

Application of the system is done by using PHP programming language and Code Igniter Framework. The system interface is divided into two parts, namely the interface for the system user and the interface for the administrator.

\section{A. End User Interface}

End users of Dutatani websites are farmers, representatives of farmer groups, academics, government representatives, and business people. Users can use some features on the website without having to login. However, especially for discussion forums, users must first login before they can send messages/opinions on the forum. The web page map (sitemap) for the end user is shown in Fig. 15.
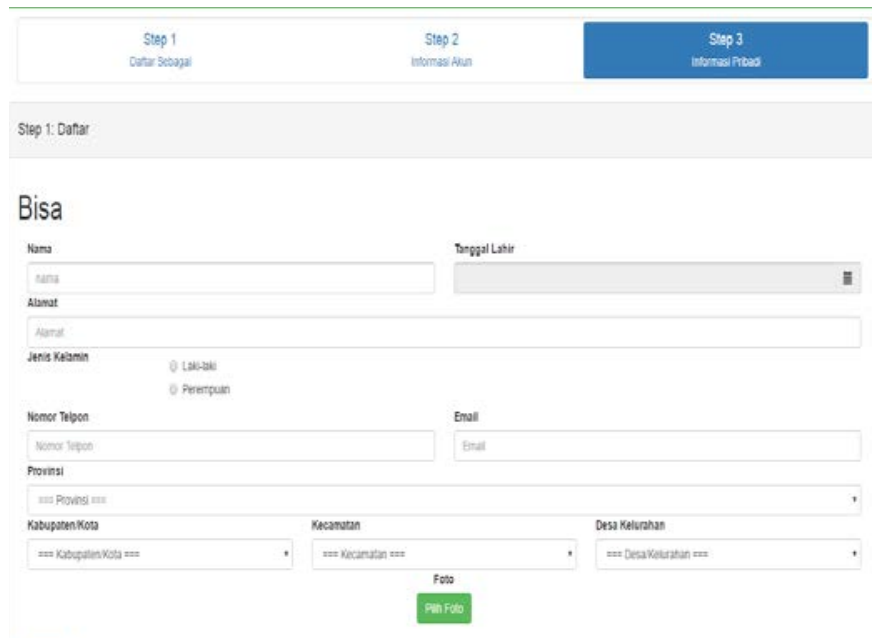

Fig. 14 Stage 3 of user registration.

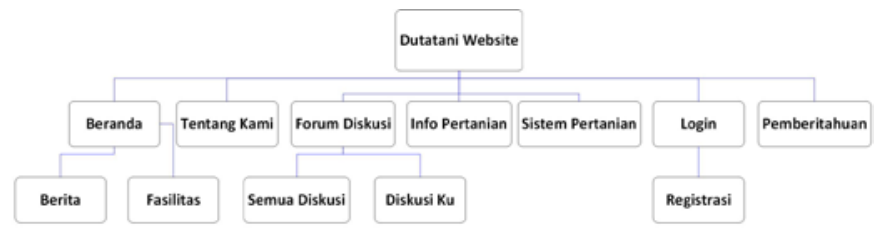

Fig. 15 Sitemap of Dutatani website for end user.

The first time the user will be confronted on the system's start page. There are some standard menus that can be accessed by the user, the homepage, about us, discussion forums, farming info, farming systems, and user logins, as shown in Fig. 16 to Fig. 19.

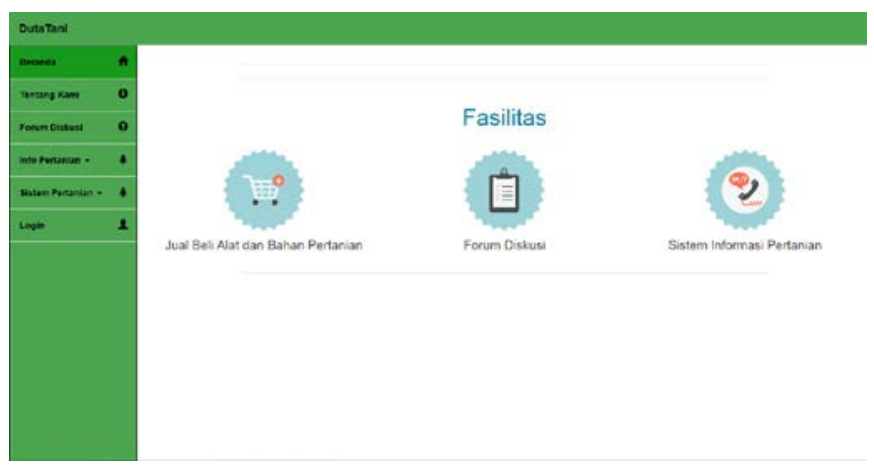

Fig. 16 Homepage of Dutatani website.

The discussion forum page, as shown in Fig. 18, serves as a means for users to exchange information about information about farming. Users can add new discussions once the user is registered and logged into the Dutatani website. When not logging in, users can only view discussions that have been created, can not comment on the discussion.

On the Login page, shown in Fig. 19, it is used by users to enter into IAIS system. Registered users must enter their user ID and keywords. If the users are not already registered on the system, they can register. 


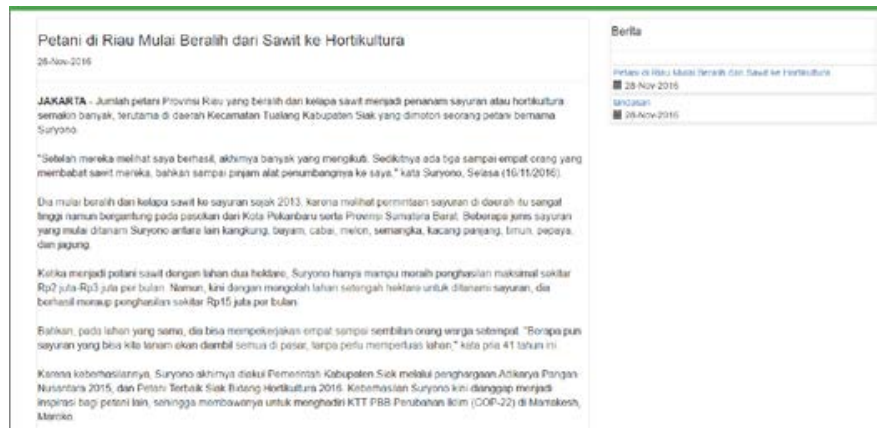

Fig. 17 News page of Dutatani website.

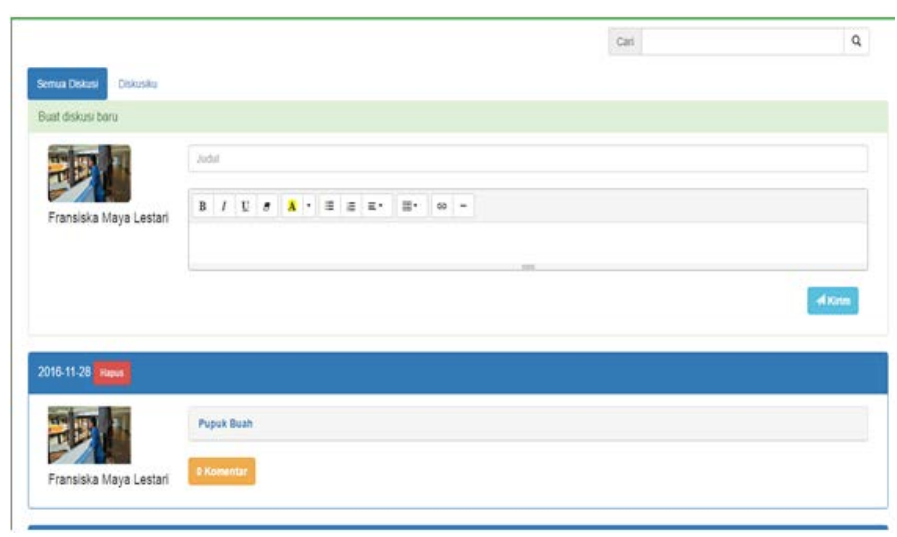

Fig. 18 Discussion page of Dutatani website.

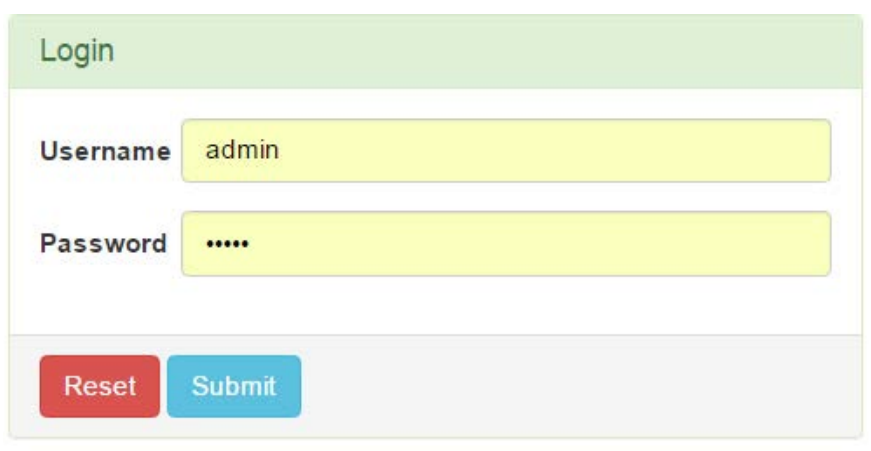

Fig. 19 User login page of Dutatani website.

\section{B. Administrator Website Interface}

The main difference between the end user page and the web administrator is the user management function. Administrators are responsible for processing user data, news data, and forum data on the website. Administrators also have the authority to remove inappropriate comments on discussion forums. The web administrator interface sitemap is shown in Fig. 20.

To login to the administrator page, the user must first log on as administrator. After it behaves, an administrator page will appear like Fig. 21. On the administrator page there is some information on the number of users based on the category and the number of users who are currently logging on the system. Through this page administrators can add categories of users if needed.

The portal administrator has authority to access some information, such as user list, user category list, admin list, unit list, and all information in the discussion forum. Fig. 22 shows the list of users by category.

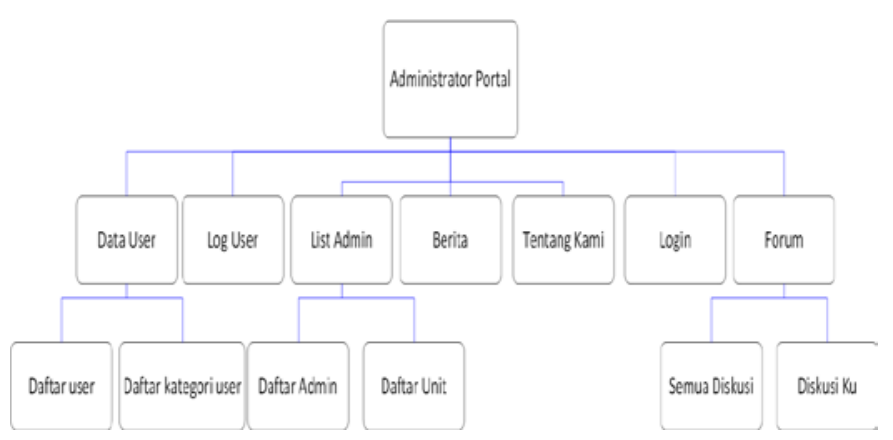

Fig. 20 Sitemap of administrator page.

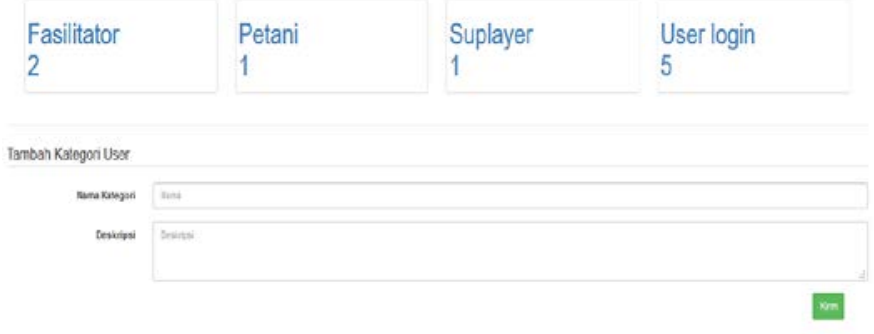

Fig. 21 Administrator homepage.

Daftar User Kategori

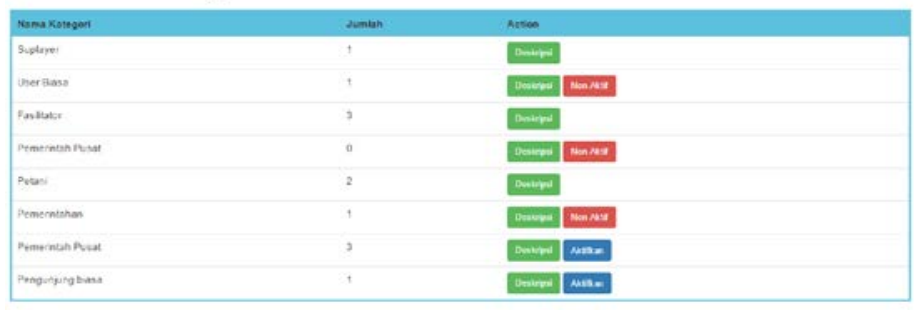

Fig. 22 User registration based on categories.

\section{System Test}

Tests were performed on application functionality. Before the testing process, firstly it was prepared data to be entered into the system. The next step was the system output matching. Examples of some system test results are presented in Table II. The test was performed on each button and application function. Based on the results of the test, it was recognized that all data entry, change, and deletion activities, as well as the appearance of information were successfully implemented without error.

\section{Analysis of RAD Method implementation}

The application of the RAD method was done by combining iterative development and prototyping technique. The analysis of the application of the RAD method was done to measure the effectiveness of application development time. The analysis of application development time was done by referring to development stage in the RAD. Table III presents the time data needed for the development of the Dutatani website. 
TABLE II

LIST OF SISTEM TEST ACTIVITIES

\begin{tabular}{|c|c|c|c|}
\hline Test ID & Description & Test Input & Remark \\
\hline 1 & Login & $\begin{array}{l}\text { Username, } \\
\text { password }\end{array}$ & Successful \\
\hline 2 & Logout & & Successful \\
\hline 3 & $\begin{array}{l}\text { Edit data } \\
\text { pengguna }\end{array}$ & $\begin{array}{l}\text { Data pribadi } \\
\text { pengguna }\end{array}$ & Successful \\
\hline 4 & $\begin{array}{l}\text { Tentang } \\
\text { Kami }\end{array}$ & Isi tentang kami & Successful \\
\hline 5 & Berita & $\begin{array}{l}\text { Judul dan isi } \\
\text { berita }\end{array}$ & Successful \\
\hline 6 & $\begin{array}{l}\text { Tambah } \\
\text { Diskusi } \\
\end{array}$ & $\begin{array}{l}\text { Judul diskusi, isi } \\
\text { diskusi }\end{array}$ & Successful \\
\hline 7 & $\begin{array}{l}\text { Hapus } \\
\text { diskusi }\end{array}$ & & Successful \\
\hline 8 & $\begin{array}{l}\text { Komentar } \\
\text { diskusi }\end{array}$ & $\begin{array}{l}\text { Isi komentar } \\
\text { diskusi }\end{array}$ & Successful \\
\hline 9 & $\begin{array}{l}\text { Tambah } \\
\text { user } \\
\text { organisasi }\end{array}$ & $\begin{array}{l}\text { Input data user } \\
\text { organisasi }\end{array}$ & Successful \\
\hline 10 & $\begin{array}{l}\text { Tambah unit } \\
\text { organisasi }\end{array}$ & $\begin{array}{l}\text { Input data unit } \\
\text { organisasi }\end{array}$ & Successful \\
\hline
\end{tabular}

TABLE III

Timeline of DUtATANi WeBsite DEVELOPMENT

\begin{tabular}{|l|l|l|c|}
\hline \multicolumn{1}{|c|}{ Model } & \multicolumn{1}{c|}{ Stages } & \multicolumn{1}{c|}{ Duration } & $\begin{array}{c}\text { Number } \\
\text { of Team }\end{array}$ \\
\hline Iterative & $\begin{array}{l}\text { Planning, } \\
\text { Analysis, Main } \\
\text { Design }\end{array}$ & $\begin{array}{l}\text { 5 Weeks } \\
\text { (May- June) }\end{array}$ & 1 \\
\hline $\begin{array}{l}\text { System } \\
\text { Prototyping }\end{array}$ & $\begin{array}{l}\text { Design, } \\
\text { Specific, } \\
\text { Implementasi, } \\
\text { Prototyping }\end{array}$ & $\begin{array}{l}\text { 16 Weeks } \\
\text { (June - } \\
\text { September) }\end{array}$ & 2 \\
\hline Iterative & Integration & $\begin{array}{l}\text { 9 Weeks } \\
\text { (September - } \\
\text { October) }\end{array}$ & 1 \\
\hline
\end{tabular}

Based on the data in Table III, it can be seen that the time required for system development was 30 weeks or 150 days. The time taken was faster than the previous plan, which was 8 months or about 35 weeks. One of the factors supporting the success of a method was the size of a relatively small system project.

However, there were few constraints in the process of system integration because there were differences in the speed of work completion on both development teams. For the prototyping stage was, two teams of developers, were Team A and Team B. Team A could complete the work within 16 weeks while Team B takes only 12 weeks, so that the new system integration process could be done after all teams finished doing the job.

In addition, the process of system integration in this approach also took a long time, due to the existence of differences in some logic and programming style that must be adjusted from both teams.

For measuring the effectiveness of the website work time with the RAD method, when compared with traditional method, in this case Waterfall model, it could be analyzed that the time of the website work with Waterfall method was estimated around 33 weeks with 5 weeks planning, analysis and main design, and 28 Week (Team A + Team B) time of design specific design, implementation, and system testing.

The results of this analysis reinforce the research that has been done before that the RAD method can accelerate the development time of the system with good software quality and this method is suitable to be implemented on small to medium scale projects. However, in its application, this method poses a risk of conflict in roles and responsibilities on the development team [2], [3]. Therefore, effective communication between team members is urgently needed [2]. The project manager also has the responsibility for continuous monitoring and evaluation of the progress of the system development project.

\section{CONCLUSION}

Based on research conducted, it has been successfully developed the website of Dutatani by applying the RAD method. The application of the method was done by combining the iterative development techniques and system prototype. The application of the RAD method could shorten system development time, but monitoring of each stage of system development was very important to be done so that the speed of workmanship of each member of the development team could always be measured and project completion time in accordance with predetermined.

After the development of the website, the next step that should be done by the IAIS development team was to form a network of cooperation with all stakeholders in the field of agriculture for the utilization of the system. Meanwhile, the development of the second phase of the Dutatani website could be done by adding the ability of service-based systems so that the flexibility of adding information and links on the website increases and easier to do.

\section{ACKNOWLEDGMENTS}

The authors thank the Ministry of Research, Technology and Higher Education of the Republic of Indonesia, the Faculty of Information Technology of Duta Wacana Christian University and the Research and Community Service Institute of Duta Wacana Christian University for providing financial support and facilities in conducting the research and publishing this article.

\section{REFERENCES}

[1] A. Dennis, B. H. Wixom and R. M. Roth, System Analysis and Design Sixth Edition, United States of America: John Wiley \& Sons, Inc, 2014.

[2] R. Naz and M. Khan, "Rapid Application Development Techniques : A Critical Review," International Journal of Software Engineering and Its Application, vol. 9 No. 11, pp. 163-176, 2015.

[3] F. Fatima , M. Javed, F. Amjad and U. G. Khan, "An Approach to Enhance Quality of The Rad Model Using Agents," The International Journal of Science and Technoledge, vol. 2, no. 13, pp. 202-210, December 2014.

[4] M. L. Despa, "Comparative Study on Software Development Methodologies," Database Systems Journal, vol. Vol V No. 3, pp. 3756, 2014.

[5] A. Mishra and D. Deepty, "A Comparative Study of Different Software 
Development Life Cycle Models in Different Scenarios," International Journal of Advance Research in Computer Science and Management Studies, vol. 1, no. 5, pp. 64-69, October 2013.

[6] "Analysis of Global e-Agriculture Survey," E-Agricultural Working Group, 2007. [Online]. Available: https://www.itu.int/net/wsis/c7/eagriculture/docs/survey-analysis-2007.pdf. [Accessed 1 April 2016].

[7] F. Brugger, "Mobile Applications in Agriculture : mAgriculture ed.", Basel: Syngenta Foundation, 2011.

[8] R. Delima, H. B. Santoso and J. Purwadi, "Kajian Aplikasi Pertanian yang Dikembangkan di Beberapa Negara Asia dan Afrika," in Prosiding Seminar Nasional Aplikasi Teknologi Informasi (SNATI), Yogyakarta, 2016.

[9] K. Annamalai and S. Rao, "What Works : ITC's E-Choupal and Profitable Rural Transformation," World Research Institute, Columbia, 2003.

[10] "e-Choupal," ITC Limited, [Online]. Available: http://www.itcportal.com/businesses/agribusiness/e-choupal.aspx. [Accessed 1 April 2016].
[11] "AMIS Agriculture Market Information System Website," Food and Agriculture Organization of United Nations (FAO), [Online]. Available: www.amisoutlook.org/technical/bangladesh/en/. [Accessed 1 April 2016].

[12] "Infotrade Market Information Services Website," Infotrade, [Online]. Available: www.infotradeuganda.com. [Accessed 1 April 2016].

[13] R. Delima and J. Purwadi, "Analisis Situs Web Pertanian Berbahasa Indonesia," in Prosiding Seminar Nasional Komputer dan Informatika Terapan (Semnaskit), Jember, 2015.

[14] R. Delima, B. H. Santoso and J. Purwadi, "Architecture Vision for Indonesian Integrated Agriculture Information Systems Using TOGAF Framework," International Conference of Informatics and Computing (ICIC), Lombok, Indonesia, October 2016.

[15] R. Delima, "Analisis Kondisi dan Kesiapan Masyarakat Tani di Daerah Istimewa Yogyakarta untuk Memanfaatkan TIK di Bidang Pertanian," Konferensi Nasional Teknologi Informasi dan Komunikasi (KNASTIK 2016) , Yogyakarta, 2016. 